of which the productive coal measures crop out at surface. Additional borings will be necessary to prove the full resources and detailed structure of the new field. Funds to undertake a programme of deep boring were granted to the Geological Survey in 1947 for the purpose of investigating the deepseated geological structure of Great Britain. It is unlikely that all the bores will give direct economic results of such importance as the Lichfield bore ; but the information gained from the bores will enable geologists to interpret the structure of the rocks at great depths beneath considerable areas of the country. Knowledge of this kind is of great general importance in the search for underground mineral and water resources. Mr. T. Eastwood, assistant director of the Geological Survey in charge of mineral deposits of England and Wales, is responsible for the work. Boring has been carried out by the Craelius Company under contract.

\section{Universities of the British Commonwealth : Con- gress in Canada}

A MEETING of representative vice-chancellors and principals of the various countries of the British Commonyoalth is to be held in Canada next month. At the gongress of Universities of the Commonwealth held Oxford in July 1948, it was decided that there should be smaller meetings of executive heads of universities annually in some part of the Commonwealth in order to discuss matters of common policy, including the implementation of the decisions of the Congress on inter-university relationships (interchange of staff, students, etc.). This, the first of such conferences, will take the form of a meeting of the Executive Council of the Association of Universities of the British Commonwealth, and will be held at Halifax, Nova Scotia, during June 10-11, followed by the annual meeting of the National Conference of Canadian Universities during June 12-15, at which the overseas representatives will be guests. The conference will conclude with a meeting in Montreal on June 17. The president of MicGill University, Dr. F. Cyril James, will preside, and the local arrangements are in the hands of Mr. T. H. Matthews, registrar of McGill University and secretary-treasurer of the National Conference of Canadian Universities.

The following is a list of delegates who will be attending the Conference. Great Britain and Ireland : Sir David Lindsay Keir (vice-chancellor, Queen's University, Belfast), Very Rev. Dr. J. Lowe (vicechancellor, University of Oxford) and Prof. Lillian Penson (vice-chancellor, University of London). Canada (representatives on Executive Council): Dr. F. Cyril James (principal, VicGill University, Montreal), Monseigneur F. Vandry (rector, Laval University, Quebec) and Dr. R. C. Wallace (principal, Queen's University, Kingston, Ontario). Australia: Prof. D. B. Copland (vice-chancellor, Australian National University) and Prof. W. Prest (dean of the Faculty of Commerce, University of Melbourne). South Africa : Dr. E. G. Malherbe (principal, University of Natal) and Dr. H. R. Raikes (vicechancellor, University of the Witwatersrand). New Zealand: Dr. R. S. Aitken (vice-chancellor, University of Otago). India and Ceylon: Dr. P. N. Banerjee (vice-chancellor, University of Calcutta) and Sir A. Lakshmanaswami Mudaliar (vice-chancellor, University of Madras). Pakistan: Dr. S. M. Hossain (vice-chancellor, University of Dacca). Other parts of the Commonwealth: Colonel Lindsay Ride (vice. chancellor, University of Hong Kong). Officers of the Association: Sir William Hamilton Fyfe (honorary treasurer, formerly vice-chancellor, Queen's University, Kingston, Ontario, and University of Aberdeen), Mr. J. F. Foster (secretary of the Association and of the Committee of Vice-Chancellors and Principals of Great Britain and Ireland, formerly registrar of the University of Melbourne, Australia) and Miss Margaret Palstra.

\section{Petroleum Oils and the Fruit-grower $\because t$}

A LECTURE giviriby Dr. T. Swarbrick to the Royal Society of Ant, January 26, described, inter alia, some intefesting features of the use of petroleum oils $\mathrm{pr}$. Chtrolling the pests of fruit trees. One fif in $y$ about their use was an occasional phyto. tosic elfect. The chemists of the Royal Dutch Shell Group have now traced the cause of this damage, and found methods for its removal. Earlier work by Chapman and Pearce indicated the necessary conditions of boiling point and viscosity which conferred insecticidal action. Petroleum can also be used as a total or selective weed-killer, and new methods of application are designed to reduce the amount of water required in spraying. Atomized oil sprays may need no more than $2 \frac{1}{4}$ gallons of spray fluid per acre for crops of small fruit.

\section{A Virus-inhibiting Protein}

A GLYCOPROTEIA which can inhibit the activity of tobacte mosaic, tom ato bushy stunt and other plant viruses ras bep isllated by $B$. Kassanis and $A$. Itapk (ys) T Ten. Microbiol., 2, No. 2; May 1948). It wo obtained from the sap of Phytolacca esculenta by tifferential precipitation with ethanol followed by adsorption on 'Celite' and elution with 10 per cent sodium chloride. The protein is unaffected by pepsin and trypsin unless it is denatured, and it is not effective against bacteriophage.

\section{Royal Institute of Chemistry}

AT the annual general meeting of the Royal Institute of Chemistry held on April 28, it was announced that H.M. the King had been graciously pleased to grant to the Institute on April 14 a new royal charter in substitution for the original charter of 1885 and the supplemental charter of 1944 . In the now charter it is made clear that the Institute is concerned with the whole profession of chemistry and not merely with that of "analytical and consulting chemistry", as stated in the original charter. The powers of the Institute have been modified in certain respects so as to facilitate the progressive development of its activities and services in the interests of the profession and of the public. The title of the Institute has been changed from "The Royal Institute of Chemistry of Great Britain and Ireland" to "The Royal Institute of Chemistry". It has been resolved to amend the by-laws so as to provide that citizens of Eire, as well as British subjects, shall be eligible for admission as members or for registration as students of the Institute. Resolutions were passed at the meeting authorizing the Council to establish, as a benevolent fund, a Residential Clubs Fund.

The following officers for 1949 were elected: President, Prof. J. W. Cook ; Vice-Presidents, Prof. F. Challenger, Mr. H. Krall, Prof. R. P. Linstead, Mr. G. Roche Lynch, Mr. J. A. Oriel, Mr. E. T Osborne; Honorary Treasurer, Dr. D. W. Kent. Jones. 